\title{
Erratum: Acute and sub-acute toxicity of the crude extracts of the aerial parts of Daucus carota L. in laboratory rats
}

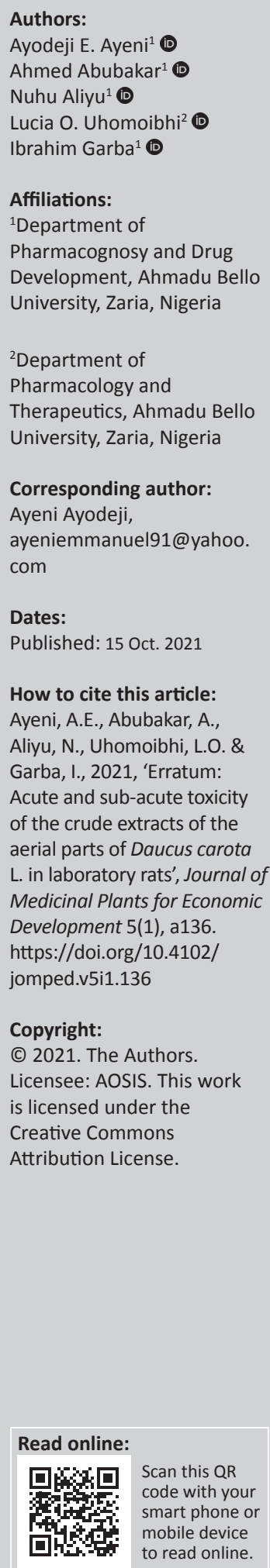

In the version of the article initially published, Ayeni, A.E., Abubakar, A., Aliyu, N., Uhomoibhi, L.O. \& Garba, I., 2019, 'Acute and sub-acute toxicity of the crude extracts of the aerial parts of Daucus carota L. in laboratory rats', Journal of Medicinal Plants for Economic Development 3(1), a69. https://doi.org/10.4102/jomped.v3i1.69, some of the $p$-values in the 'Results' section was incorrectly displayed as $p$-. The values should have reflected as $p \leq$.

The 'Results' section is hereby updated to:

\section{Results}

\section{Acute toxicity}

The acute oral toxicity of graded doses of the n-hexane, ethyl acetate and methanol extracts of D. carota aerial part was administered, respectively. The animals were observed for 14 days, and no mortality or any toxic signs such as tiredness, weakness, convulsion, hyperactiveness, dullness, diarrhoea and diuresis were noticed in the extracts, respectively, even at a high dose of $5000 \mathrm{mg} / \mathrm{kg}$.

\section{Sub-chronic toxicity}

\section{Body weight}

During the second week, there was significant $(p \leq 0.05)$ weight loss in the HAEDC and MAEDC with 500, 1000 and $1500 \mathrm{mg} / \mathrm{kg}$ lost when compared with a control group and there was no significant difference $(p \geq 0.05)$ in the EAEDCtreated group (Table 1).

\section{Haematological parameters}

The effects of the daily oral administration of the HAEDC, EAEDC and MAEDC showed a statistically significant decrease $(p \leq 0.05)$ on the red RBC at different doses when compared with the control group. However, there was a significant $(p \leq 0.05)$ increase in the MCV of HAEDC and EAEDC with doses of $1000 \mathrm{mg} / \mathrm{kg}$ and $1500 \mathrm{mg} / \mathrm{kg}$ when compared with the control group. Furthermore, EAEDC at a dose of $500 \mathrm{mg} / \mathrm{kg}$ showed a significant $(p \leq 0.05)$ increase in the $\mathrm{MCH}$ when compared with the control group (Table 2).

\section{Biochemical parameters}

There was no significant difference between the serum liver biomarker, AST, alanine amino transferase (ALT), TP and ALB in the treated group and control group. However, there was a significant $(p \leq 0.05)$ decrease in ALP of all the treated groups when compared with control group (Table 3).

There was no significant change in the serum kidney biomarkers (urea, sodium, potassium, creatinine and chloride) in the treated group when compared with the control group. However, there was a significant $(p \leq 0.05)$ decrease in the serum bicarbonate level in HAEDC with $500 \mathrm{mg} / \mathrm{kg}, 1000 \mathrm{mg} / \mathrm{kg}$ and $1500 \mathrm{mg} / \mathrm{kg}$ and MAEDC with $1000 \mathrm{mg} / \mathrm{kg}$ and $1500 \mathrm{mg} / \mathrm{kg}$ body weight when compared with the control group (Table 4).

The publisher apologises for any inconvenience caused. 


\section{Acute and sub-acute toxicity of the crude extracts of the aerial parts of Daucus carota $\mathrm{L}$. in laboratory rats}

\begin{tabular}{|c|c|}
\hline \multicolumn{2}{|c|}{$\begin{array}{l}\text { Authors: } \\
\text { Ayodeji E. Ayeni }^{1} \text { (D) } \\
\text { Ahmed Abubakar }^{1} \text { (D) } \\
\text { Nuhu Aliyu } \\
\text { Lucia O. Uhomoibhi }^{1} \\
\text { Ibrahim Garba }^{1} \text { (D) }\end{array}$} \\
\hline \multicolumn{2}{|c|}{$\begin{array}{l}\text { Affiliations: } \\
{ }^{1} \text { Department of } \\
\text { Pharmacognosy and Drug } \\
\text { Development, Ahmadu Bello } \\
\text { University, Zaria, Nigeria }\end{array}$} \\
\hline \multicolumn{2}{|c|}{$\begin{array}{l}\text { ²Department of } \\
\text { Pharmacology and } \\
\text { Therapeutics, Ahmadu Bello } \\
\text { University, Zaria, Nigeria }\end{array}$} \\
\hline \multicolumn{2}{|c|}{$\begin{array}{l}\text { Corresponding author: } \\
\text { Ayeni Ayodeji, } \\
\text { ayeniemmanuel91@ } \\
\text { yahoo.com }\end{array}$} \\
\hline \multicolumn{2}{|c|}{$\begin{array}{l}\text { Dates: } \\
\text { Received: } 16 \text { Feb. } 2019 \\
\text { Accepted: } 24 \text { June } 2019 \\
\text { Published: } 10 \text { Oct. } 2019\end{array}$} \\
\hline \multicolumn{2}{|c|}{$\begin{array}{l}\text { How to cite this article: } \\
\text { Ayeni, A.E., Abubakar, A., } \\
\text { Aliyu, N., Uhomoibhi, L.O. \& } \\
\text { Garba, I., 2019, 'Acute and } \\
\text { sub-acute toxicity of the } \\
\text { crude extracts of the aerial } \\
\text { parts of Daucus carota L. } \\
\text { in laboratory rats', Journal } \\
\text { of Medicinal Plants for } \\
\text { Economic Development 3(1), } \\
\text { a69. https://doi.org/10.4102/ } \\
\text { jomped.v3i1.69 }\end{array}$} \\
\hline \multicolumn{2}{|c|}{$\begin{array}{l}\text { Copyright: } \\
\text { (C) 2019. The Authors } \\
\text { Licensee: AOSIS. This } \\
\text { is licensed under the } \\
\text { Creative Commons } \\
\text { Attribution License. }\end{array}$} \\
\hline \multicolumn{2}{|l|}{ Read online: } \\
\hline 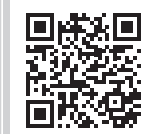 & $\begin{array}{l}\text { Scan this QR } \\
\text { code with your } \\
\text { smart phone or } \\
\text { mobile device } \\
\text { to read online. }\end{array}$ \\
\hline
\end{tabular}

Background: Daucus carota L. belongs to the family Apiaceae and it is commonly known as carrot. The aerial part is used in some Northern parts of Nigeria as a livestock feed without scientific evidence of its safety to animal and man.

Aim: The study assessed the safety margins of the D. carota aerial parts.

Setting: The aerial part of D. carota were sourced from cultivated farmland at the outskirts of Samaru, Sabon Gari Local Government Area of Kaduna State and authenticated at Herbarium Unit of the Department of Botany, Ahmadu Bello University Zaria, Nigeria. The aerial parts were air-dried under shade, pulverised and stored properly for analysis.

Methods: According to the Organization for Economic Cooperation and Development (OECD) method, the acute and sub-acute toxicity studies were carried on the crude extracts of the aerial parts to evaluate the safety of the healthy Wistar rats.

Results: The findings from the oral acute toxicity study showed that there was no sign of toxicity and mortality at $5000 \mathrm{mg} / \mathrm{kg}$ in the $n$-hexane, ethyl acetate and methanol extracts. The sub-acute toxicity graded doses of $500 \mathrm{mg} / \mathrm{kg}, 1000 \mathrm{mg} / \mathrm{kg}$ and $1500 \mathrm{mg} / \mathrm{kg}$ of these extracts revealed a significant difference $(p \leq 0.05)$ on body weight, haematological parameters, liver and kidney function parameters. The histopathological effects of the extracts revealed different morphological alterations in the liver and kidney when compared with the control group.

Conclusion: The study concluded that the aerial parts of D. carota might not be safe for livestock and its consumption could be capable of causing liver, kidney, tissue injury and other related diseases to animal and man.

Keywords: toxicity; aerial parts; Daucus carota; man.

\section{Introduction}

Vegetables have been one of the regularly recommended cheap solutions to the malnutrition or malnourishment challenge experienced worldwide (Bello et al. 2019). They play a very important role in our diet and are most readily available sources of carbohydrates, fats, proteins, vitamins, minerals and essential amino acids (Fasuyi 2006; Sharma \& Kumar 2013). Many vegetables are mainly consumed for their nutritional value without much consideration for their safety and possible contamination with related lethal effects. Aside from the nutritional intake, they have the ability to synthesize several secondary metabolites of relatively complex structures possessing antioxidants (Yadav et al. 2013). These metabolites produce specific effects on the physiology of human beings and other organisms. Recent reports indicate that there is an inverse relationship between the dietary intake of antioxidant-rich foods and the incidence of human diseases (Latifou et al. 2016). Despite their advantages, several studies have established that some vegetable species are potentially toxic to humans and animals because plant chemical compounds are produced as part of the plant's defence against being eaten by pests and herbivores or to gain an advantage over competing with other plants (Orech et al. 2005; Latifou et al. 2016) with the potential to be toxic to humans and livestock.

However, safe natural products through low or little toxic contents and wide safety margins would benefit society towards further utilisation (Ali-Abdel-Rahman et al. 2011; FAO/WHO 2002; Sanders et al. 2010). Gandhare, Kavimani and Rajkapoor (2013) reported that the purpose of toxicity testing is to provide an adequate database to make decisions concerning the toxicology properties of chemical and commercial products. Its assessment could guide the utilisation or condition of substances including natural products under short- and long-term effects and provides adequate information about the product (Gandhare, Kavimani \& Rajkapoor 2013; Obidike \& Salawu 2013). 
Daucus carota L. commonly called carrot, belongs to the family Apiaceae (Pimenov \& Leonov 2004). It is native to Western or near East Asia, Tropical Africa, North and South America (Heywood et al. 2008). The root is a rich source of vitamin $\mathrm{A}$ and $\mathrm{B}$ that can serve as antioxidants and can inhibit or reduce cardiovascular diseases (Dalvir et al. 2016). Carrot is an important vegetable crop that has contributed to human health (Shelly 2012). Ayeni et al. (2018) reported on the phytochemicals, nutraceuticals and antioxidants potentials of carrots aerial parts and its possible utilisation as vegetables. However, the aerial part of carrot is used as component in livestock feed in some parts of Northern Nigeria without information on its toxicity. The present study was designed to investigate the possible toxic effects of the crude extracts of $D$. carota aerial parts and to determine safe levels in laboratory rats.

\section{Materials and methods}

\section{Plant collection, preparation and identification}

The Daucus carota L. aerial part was collected around the Samaru farmlands, Sabon Gari Local Government Area of the Kaduna State. The whole plant of D. carota (root inclusive was identified and authenticated by Mallam Namadi Sanusi, in the Herbarium Unit of the Department of Botany, ABU, Zaria, Nigeria and voucher specimen [no.: 12034]) was deposited. The aerial parts were air-dried under shade, pulverised and stored in an airtight container made of plastics for further use.

\section{Extraction of Daucus carota aerial part}

The powdered D. carota aerial parts $(1.2 \mathrm{~kg})$ were extracted successively in different portions of $n$-hexane, ethyl acetate and methanol successively using cold solvent maceration. It was shaken intermittently using the flask shaker for 72 hours. The filtrate obtained was concentrated to dryness in a rotor evaporator under vacuum and later in the oven $\left(45^{\circ} \mathrm{C}\right)$. The extracts obtained were stored in a desiccator (Brain \& Tuner 1975). The $n$-hexane, ethyl acetate and methanol extract were coded as HAEDC ( $n$-hexane aerial part extract of Daucus carota), EAEDC (ethyl acetate aerial part extract of Daucus carota) and MAEDC (methanol aerial part extract of Daucus carota), respectively.

\section{Experimental animals}

Sixty-five (65) apparently healthy Wistar rats (Rattus albus) of both sexes weighing 100-120 g were obtained from the Animal House, Department of Pharmacology and Therapeutics, Ahmadu Bello University, Zaria, Nigeria. The Wistar rats were housed in well-ventilated cages under standard environmental conditions $\left(22 \pm 2{ }^{\circ} \mathrm{C}, 12\right.$ :12-h dark/ light cycle, frequent air change), fed with normal feed and allowed free access to water ad libitum. The oral gavage route of administration was used throughout the study for the control and the treated groups in the acute and sub-acute toxicity studies of the extracts.

\section{Acute toxicity}

Healthy Wistar rats (15, average weight 100-120 g) were used for the oral acute toxicity testing of the extracts (HAEDC, EAEDC and MAEDC) using the fixed-dose method (new Organization for Economic Cooperation and Development [OECD] FDM test guideline 420).

According to the Organization for Economic Cooperation Development (OECD 2011) guidelines, five animals for each extract were administered single oral doses each at $5 \mathrm{mg} / \mathrm{kg}$, $50 \mathrm{mg} / \mathrm{kg}, 500 \mathrm{mg} / \mathrm{kg}, 2000 \mathrm{mg} / \mathrm{kg}$ and $5000 \mathrm{mg} / \mathrm{kg}$ body weight. The Wistar rats were observed for toxicity signs for the first 30 minutes, $1 \mathrm{~h}$ and at an interval of $24 \mathrm{~h}$ for 14 days for mortality and toxic signs such as convulsion, hyperactivity, dullness, diarrhoea, increased diuresis, tiredness, weakness, excessive urination and so on. The median lethal dose $\left(\mathrm{LD}_{50}\right)$ was determined as reported by OECD (2011) and Parasuraman (2011).

\section{Sub-acute toxicity studies}

The 28 days' study was carried out in accordance with OECD (2011), Olorunnisola et al. (2012), Parasuraman (2011) and Ugbogu et al. (2016). Fifty healthy Wistar rats were used and divided into four groups of five animals each. Group 1, which served as the control, received distilled water $(1 \mathrm{~mL} / \mathrm{kg})$, while rats in groups 2, 3 and 4 received 500, 1000 and $1500 \mathrm{mg} / \mathrm{kg}$ body weight oral doses daily of the $n$-hexane extract (HAEDC), respectively, for 28 days. This grouping and dosing were repeated for the EAEDC and MAEDC extracts, respectively. The animals were fasted overnight prior to the first dosing; after fasting, the animals were weighed before the test extract was administered via the oral route. The animals were observed daily for general symptoms and signs of toxicity. All the rats were allowed free access to food and water throughout the duration of the study. Thirty per cent of the highest dose of $\mathrm{LD}_{50}$ was based on the selection of the graded doses for the sub-acute toxicity study, as also reported by Adesegun, Celestina and Coker (2016).

\section{Body weight}

The body weight of each rat was measured once before treatment (day 0), and then subsequently every week on days 7, 14 and 28 of treatment (Baghiani et al. 2013).

\section{Collection of blood samples}

Five millilitres of blood samples of the euthanised (with diethyl ether) animals were collected by puncturing the prominent jugular vein with syringe needles into labelled heparinised (ethylene diamine tetra acetate [EDTA] bottles) and non-heparinised bottles (without EDTA). The heparinised blood samples were used for haematological evaluation, while the non-heparinised blood was allowed to coagulate, centrifuged and the sera that were separated were analysed for biochemical parameters. 


\section{Haematological parameters}

The blood indices including the white blood cell (WBC), red blood cell (RBC), haemoglobin (Hgb), packed cell volume (PCV), mean corpuscular volume (MCV), mean corpuscular haemoglobin $(\mathrm{MCH})$ and mean corpuscular haemoglobin concentration (MCHC) were assayed using automated Hematology Analyzer (Mind-ray BC-3600, Guangzhou Medical Equipment Co., Ltd, China) (Jaijoy et al. 2011).

\section{Biochemical parameters}

The blood samples for biochemical analyses were collected into plain universal bottles, allowed to clot and centrifuged at 3500 revolutions per minute (rpm) for 10 minutes from the three different extracts. The sera were separated and stored at $-4{ }^{\circ} \mathrm{C}$.
The biochemical parameters evaluated included alanine aminotransferase (ALT), aspartate aminotransferase (AST), alkaline phosphatase (ALP), total protein (TP), albumin (ALB), sodium, potassium, creatinine, chloride, urea and bicarbonate as liver and kidney function tests by the colorimetric method using Randox Assay Kits and Automated Biochemistry Analyzer (Jaijoy et al. 2011; Park, Choi \& Kwak 2011).

\section{Histopathological effects of the Daucus carota $n$-hexane, ethyl acetate and methanol extracts}

The kidney and liver of the euthanised rats were harvested and sliced $3 \mathrm{~cm}-4 \mathrm{~cm}$ thick and fixed in 10\% formalin solution for sectioning. The fixed specimens were sliced, processed and embedded into paraffin blocks. The blocks were cut into $5 \mu \mathrm{m}$ thick paraffin sections by a rotary microtome. The sections were

\begin{tabular}{|c|c|c|c|c|c|}
\hline Treatment (mg/kg) & Pre-treatment & Week 1 & Week 2 & Week 3 & Week 4 \\
\hline D/water (1 mL/kg) & $92.00 \pm 8.37$ & $96.60 \pm 8.91$ & $98.00 \pm 15.38$ & $102.60 \pm 20.43$ & $115.00 \pm 26.56$ \\
\hline HAEDC 500 & $96.00 \pm 5.48$ & $88.00 \pm 7.31$ & $97.40 \pm 9.48 \dagger$ & $132.00 \pm 10.79$ & $138.00 \pm 12.83$ \\
\hline HAEDC 1000 & $94.00 \pm 5.48$ & $85.00 \pm 11.55$ & $88.20 \pm 7.29 \dagger$ & $110.40 \pm 26.41$ & $118.80 \pm 23.32$ \\
\hline HAEDC 1500 & $94.00 \pm 5.48$ & $96.60 \pm 24.88$ & $80.80 \pm 20.39 \dagger$ & $100.40 \pm 19.75$ & $118.00 \pm 21.01$ \\
\hline EAEDC 500 & $92.00 \pm 4.47$ & $95.00 \pm 11.02$ & $90.6 \pm 8.44$ & $99.00 \pm 11.77$ & $111.40 \pm 6.35$ \\
\hline EAEDC 1000 & $100.00 \pm 0.00$ & $109.60 \pm 11.13$ & $105.80 \pm 8.79$ & $114.60 \pm 10.81$ & $122.20 \pm 12.62$ \\
\hline EAEDC 1500 & $94.00 \pm 5.48$ & $98.00 \pm 10.52$ & $98.60 \pm 10.48$ & $104.80 \pm 12.09$ & $116.60 \pm 13.97$ \\
\hline MAEDC 500 & $90.00 \pm 0.00$ & $92.20 \pm 9.68$ & $89.00 \pm 14.19 \dagger$ & $86.40 \pm 7.89$ & $101.40 \pm 13.52$ \\
\hline MAEDC 1000 & $90.00 \pm 0.00$ & $90.20 \pm 18.87$ & $85.00 \pm 13.98 \dagger$ & $95.60 \pm 11.93$ & $102.00 \pm 12.96$ \\
\hline MAEDC 1500 & $92.00 \pm 4.47$ & $90.20 \pm 10.94$ & $75.40 \pm 6.20 \dagger$ & $97.60 \pm 10.26$ & $104.20 \pm 12.52$ \\
\hline
\end{tabular}

Note: Data were analysed using one-way analysis of variance followed by the Bonferroni post hoc test.

D/water, distilled water; HAEDC, $n$-hexane aerial part extract of Daucus carota; EAEDC, ethyl acetate aerial part extract of Daucus carota; MAEDC, methanol aerial part extract of Daucus carota

$\dagger$, The mean difference is statistically significant $(p \leq 0.05)$ compared to the control. Mean \pm standard deviation $(n=5)$.

TABLE 2: Effects of oral administration of $n$-hexane, ethyl acetate and methanol extracts of Daucus carota aerial part on the haematological parameters of Wistar rats after 28 days.

\begin{tabular}{|c|c|c|c|c|c|c|c|}
\hline Treatment (mg/kg) & WBC $\left(\times 10^{9} / L\right)$ & $\operatorname{RBC}\left(\times 10^{9} / \mathrm{L}\right)$ & $\mathrm{Hgb}(\mathrm{g} / \mathrm{dL})$ & НCT (\%) & $\operatorname{MCV}\left(\mu \mathrm{m}^{3}\right)$ & $\mathrm{MCH}(\mathrm{pg})$ & $\mathrm{MCHC}(\mathrm{g} / \mathrm{dL})$ \\
\hline $\mathrm{D} /$ water $(1 \mathrm{~mL} / \mathrm{kg})$ & $8.63 \pm 2.65$ & $7.62 \pm 0.40$ & $14.82 \pm 1.33$ & $45.07 \pm 3.80$ & $59.33 \pm 6.86$ & $19.50 \pm 2.39$ & $32.87 \pm 0.25$ \\
\hline HAEDC 500 & $7.87 \pm 2.29$ & $4.62 \pm 0.28 \dagger$ & $11.37 \pm 2.48$ & $35.47 \pm 6.43$ & $76.80 \pm 13.18$ & $24.63 \pm 5.15$ & $31.87 \pm 1.36$ \\
\hline HAEDC 1000 & $7.27 \pm 3.41$ & $3.17 \pm 1.05 \dagger$ & $8.20 \pm 2.45$ & $25.17 \pm 8.93$ & $80.13 \pm 5.03 \dagger$ & $26.27 \pm 2.16$ & $32.70 \pm 1.78$ \\
\hline HAEDC 1500 & $5.93 \pm 18.35$ & $3.21 \pm 1.35 \dagger$ & $8.53 \pm 3.12$ & $27.17 \pm 10.08$ & $84.57 \pm 2.26 \dagger$ & $26.87 \pm 1.39$ & $31.77 \pm 0.85$ \\
\hline EAEDC 500 & $5.53 \pm 0.55$ & $4.06 \pm 0.29 \dagger$ & $11.53 \pm 0.95$ & $37.93 \pm 0.40$ & $84.37 \pm 3.82 \dagger$ & $28.53 \pm 1.50 \dagger$ & $31.23 \pm 1.27$ \\
\hline EAEDC 1000 & $7.97 \pm 3.60$ & $3.93 \pm 1.35 \dagger$ & $3.93 \pm 1.35 \dagger$ & $33.83 \pm 6.95$ & $54.60 \pm 3.57 \dagger$ & $23.63 \pm 4.11$ & $32.17 \pm 0.55$ \\
\hline EAEDC 1500 & $7.77 \pm 3.33$ & $3.73 \pm 1.14 \dagger$ & $14.70 \pm 2.09$ & $43.6 \pm 7.02$ & $56.60 \pm 7.46 \dagger$ & $19.07 \pm 1.77$ & $33.77 \pm 1.27$ \\
\hline MAEDC1000 & $5.67 \pm 0.93$ & $3.76 \pm 0.69 \dagger$ & $9.83 \pm 1.55$ & $30.77 \pm 5.68$ & $81.83 \pm 2.70$ & $26.20 \pm 0.79$ & $32.03 \pm 0.86$ \\
\hline MAEDC 1500 & $5.37 \pm 0.23$ & $2.89 \pm 2.15 \dagger$ & $9.39 \pm 4.79$ & $28.53 \pm 15.03$ & $69.53 \pm 30.73$ & $48.40 \pm 34.56$ & $31.43 \pm 2.21$ \\
\hline
\end{tabular}

D/water, distilled water; HAEDC, $n$-hexane aerial part extract of Daucus carota; EAEDC, ethyl acetate aerial part extract of Daucus carota; MAEDC, methanol aerial part extract of Daucus carota; WBC, white blood cell; RBC, red blood cell; Hgb, haemoglobin; HCT, haematocrit; MCV, mean corpuscular volume; MCH, mean corpuscular haemoglobin; MCHC, mean corpuscular haemoglobin concentration.

$\dagger$, The mean difference is statistically significant $(p \leq 0.05)$ compared to control. Mean \pm standard deviation $(n=5)$.

TABLE 3: Effect of $n$-hexane, ethyl acetate and methanol extracts of Daucus carota aerial part on hepatic indices of Wistar rats after oral administration for 28 days.

\begin{tabular}{|c|c|c|c|c|c|}
\hline Treatment (mg/kg) & ALT (IU/L) & AST (IU/L) & ALP (IU/L) & $\mathrm{TP}(\mathrm{g} / \mathrm{dL})$ & ALB $(\mathrm{g} / \mathrm{dL})$ \\
\hline D/water (1 mL/kg) & $18.67 \pm 3.06$ & $21.33 \pm 18.90$ & $72.26 \pm 14.20$ & $7.31 \pm 0.76$ & $2.59 \pm 0.13$ \\
\hline HAEDC 500 & $6.33 \pm 4.16$ & $28.33 \pm 1.53$ & $17.14 \pm 5.74 \dagger$ & $5.76 \pm 21.30$ & $2.59 \pm 0.36$ \\
\hline HAEDC 1000 & $12.33 \pm 7.00$ & $28.33 \pm 5.86$ & $16.49 \pm 0.68 \dagger$ & $5.21 \pm 0.78$ & $2.68 \pm 0.54$ \\
\hline HAEDC 1500 & $15.00 \pm 4.51$ & $27.33 \pm 4.61$ & $11.29 \pm 2.06 \dagger$ & $6.42 \pm 1.31$ & $2.43 \pm 0.15$ \\
\hline EAEDC 500 & $18.67 \pm 0.58$ & $21.33 \pm 4.04$ & $42.52 \pm 2.22 \dagger$ & $6.09 \pm 0.26$ & $2.68 \pm 0.22$ \\
\hline EAEDC 1000 & $20.00 \pm 5.19$ & $26.33 \pm 4.62$ & $32.88 \pm 4.61 \dagger$ & $6.07 \pm 0.42$ & $2.75 \pm 0.16$ \\
\hline EAEDC 1500 & $17.33 \pm 2.52$ & $28.00 \pm 3.61$ & $28.21 \pm 12.93 \dagger$ & $7.58 \pm 1.67$ & $2.59 \pm 0.40$ \\
\hline MAEDC 500 & $21.67 \pm 5.03$ & $31.00 \pm 8.54$ & $12.15 \pm 3.77 \dagger$ & $7.24 \pm 1.97$ & $2.31 \pm 0.26$ \\
\hline MAEDC1000 & $20.67 \pm 4.04$ & $23.33 \pm 2.08$ & $15.18 \pm 4.63 \dagger$ & $7.71 \pm 2.89$ & $2.27 \pm 0.15$ \\
\hline MAEDC 1500 & $23.67 \pm 2.51$ & $27.00 \pm 3.00$ & $11.28 \pm 13.86 \dagger$ & $6.58 \pm 0.55$ & $2.53 \pm 0.30$ \\
\hline
\end{tabular}

D/water, distilled water; HAEDC, $n$-hexane aerial part extract of Daucus carota; EAEDC, ethyl acetate aerial part extract of Daucus carota; MAEDC, methanol aerial part extract of Daucus carota; ALT, alanine amino transferase; AST, aspartate amino transferase; ALP, alkaline phosphatase; TP, total protein; ALB, albumin.

$\dagger$, The mean difference is statistically significant $(p \leq 0.05)$ compared to the control. Mean \pm standard deviation $(n=5)$. Data were analysed using one-way analysis of variance followed by the Bonferroni post hoc test. 
TABLE 4: Effect of $n$-hexane, ethyl acetate and methanol extracts of Daucus carota aerial part on renal indices of Wistar rats after oral administration for 28 days.

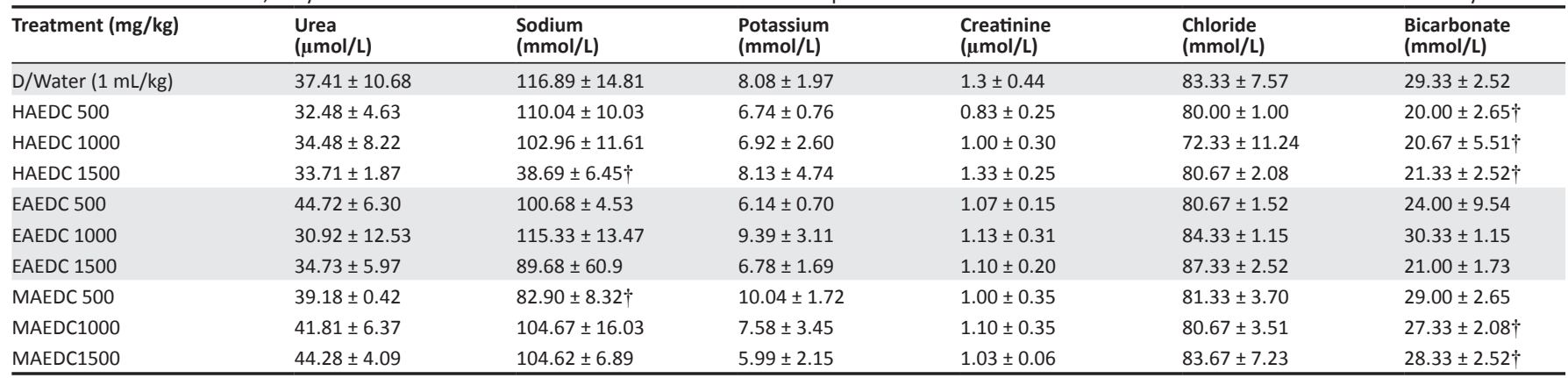

D/water, distilled water; HAEDC, $n$-hexane aerial part extract of Daucus carota; EAEDC, ethyl acetate aerial part extract of Daucus carota; MAEDC, methanol aerial part extract of Daucus carota. $\dagger$, The mean difference is statistically significant $(p \leq 0.05)$ compared to the control. Mean \pm standard deviation $(n=5)$. Data were analysed using one-way analysis of variance followed by the Bonferroni post hoc test.
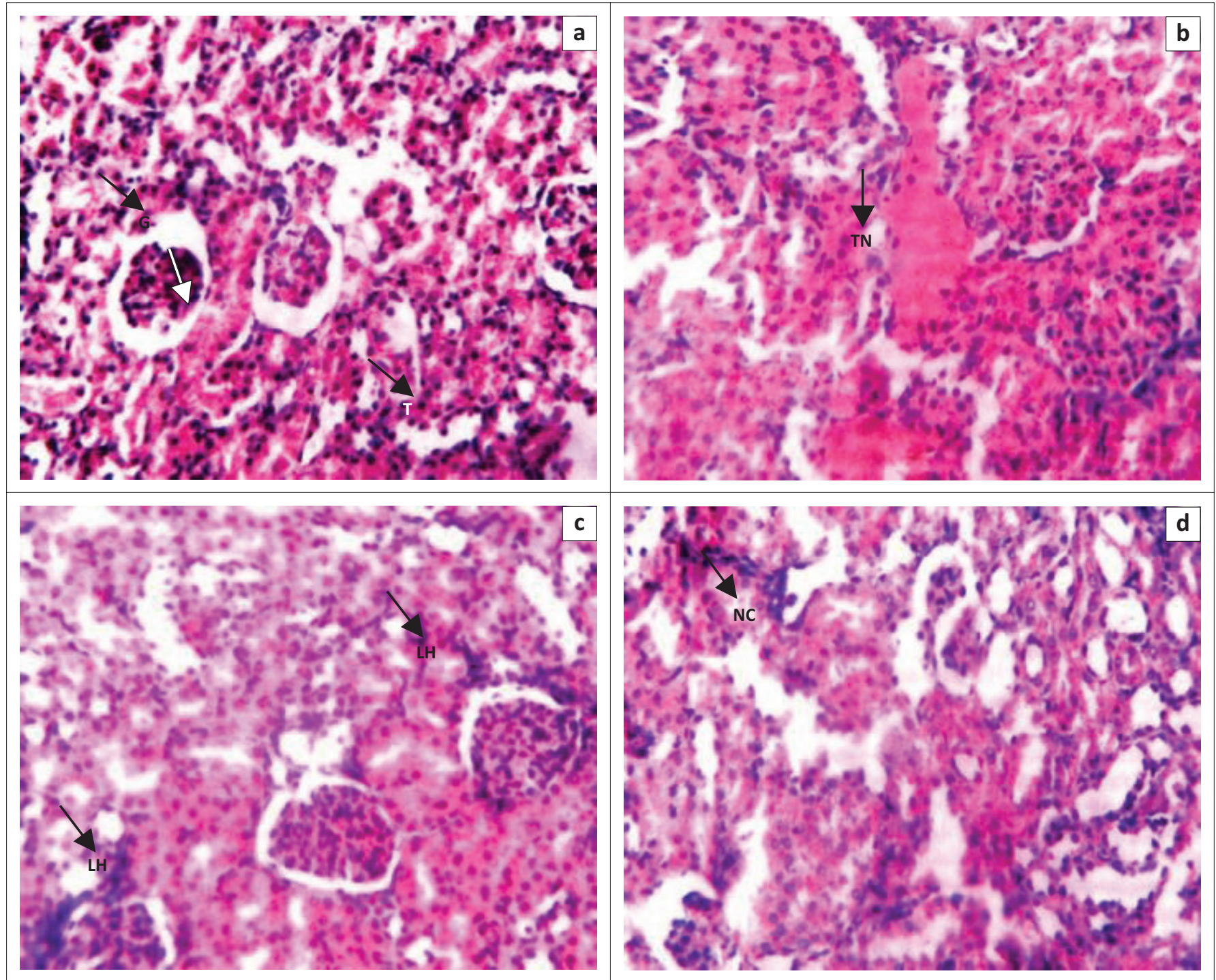

G, glomerular; T, normal tubules; TN, tubular necrosis; LH, lymphocyte hyperplasia; NC, slight hepatic necrosis.

FIGURE 1: Photomicrograph showing the kidney section of (a) control group (1 $\mathrm{mL} / \mathrm{kg}$ distilled water) shows the normal architecture tubules (T) and glomerulus; (b) treated with $500 \mathrm{mg} / \mathrm{kg}$ of $n$-hexane extract shows moderate and slight tubular necrosis; (c) treated with $1000 \mathrm{mg} / \mathrm{kg}$ of $n$-hexane extract shows moderate lymphocyte hyperplasia; (d) treated with $1500 \mathrm{mg} / \mathrm{kg}$ of $n$-hexane extract shows tubular necrosis moderate and slight lymphocyte hyperplasia necrosis (haematoxylin and eosin stain; original magnification $\times 400$ ).

stained with haematoxylin and eosin (H\&E) for histological observations. The method of Olorunnisola et al. (2012) and Ugbogu et al. (2016) was used during the histopathology investigation for possible tissue lesions. Photomicrographs of the tissues were taken at the magnification of $\times 400$.

\section{Statistical analysis}

All data were expressed as mean \pm standard deviation and subjected to one-way analysis of variance (ANOVA) followed by the Bonferroni test for multiple comparisons, and values were taken at $p \leq 0.05$ as significant. 

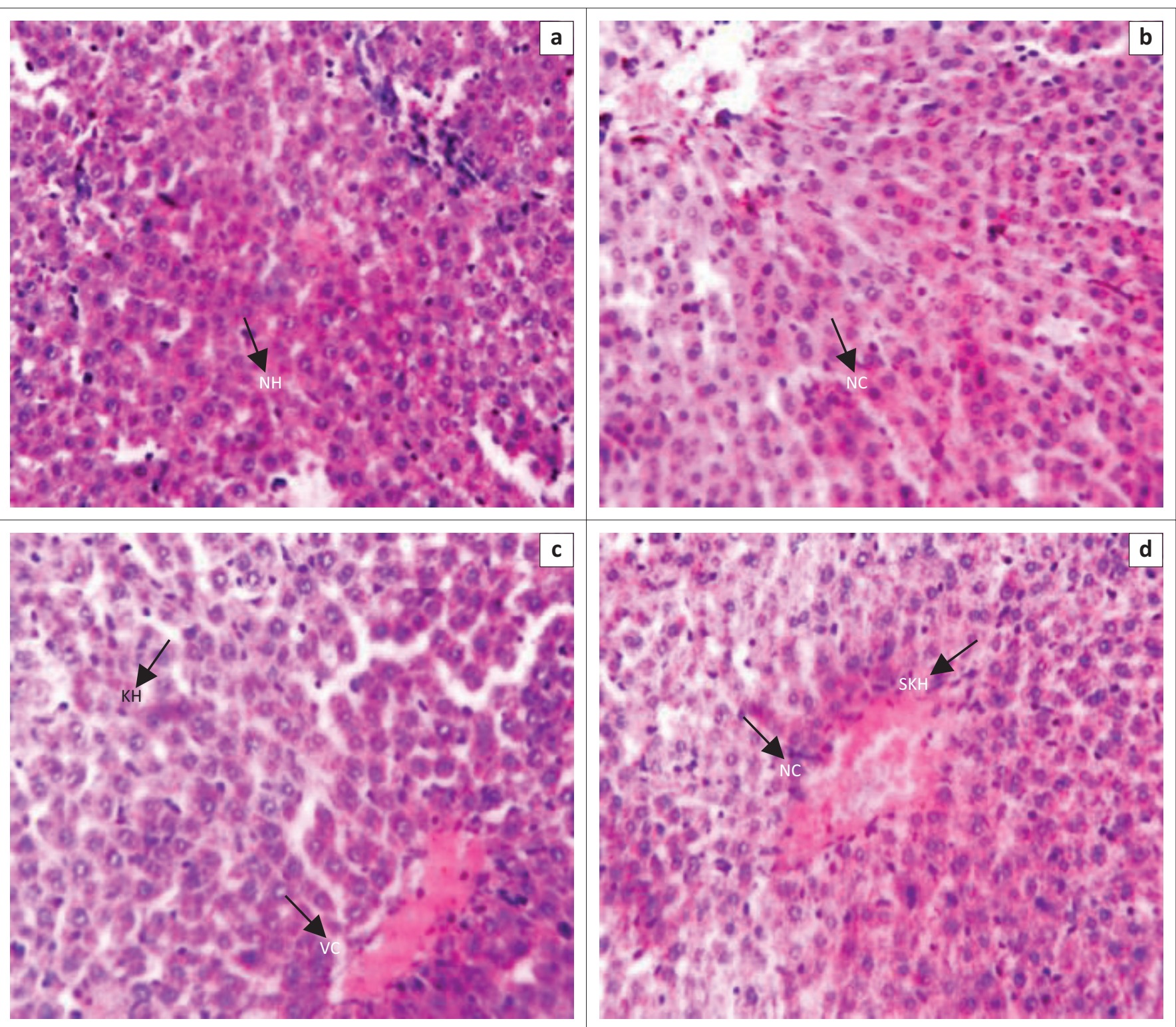

VC, vascular congestion necrosis; NC, slight hepatic necrosis; NH, normal hepatocytes; SKH, slight Kupfer cell hyperplasia.

FIGURE 2: Photomicrograph showing the liver section of (a) control group (1 mL/kg distilled water) shows the normal hepatocytes; (b) rat treated with $500 \mathrm{mg} / \mathrm{kg}$ of $n$-hexane had slight hepatic necrosis with moderate lymphocyte hyperplasia; (c) treated with $1000 \mathrm{mg} / \mathrm{kg}$ of $n$-hexane extract had vascular congestion with Kupfer cell hyperplasia; (d) treated with $1500 \mathrm{mg} / \mathrm{kg}$ of $n$-hexane extract shows slight hepatocellular necrosis with Kupfer cell hyperplasia (haematoxylin and eosin stain; original magnification $\times 400$ ).

\section{Ethical considerations}

Ethical approval for the use of laboratory animals was obtained from the Animal Rights Ethical Committee with the approval number ABUCAUC/2017/005.

\section{Results}

\section{Acute toxicity}

The acute oral toxicity of graded doses of the $n$-hexane, ethyl acetate and methanol extracts of $D$. carota aerial part was administered, respectively. The animals were observed for 14 days, and no mortality or any toxic signs such as tiredness, weakness, convulsion, hyperactiveness, dullness, diarrhoea and diuresis were noticed in the extracts, respectively, even at a high dose of $5000 \mathrm{mg} / \mathrm{kg}$.

\section{Sub-chronic toxicity}

\section{Body weight}

During the second week, there was significant $(p-0.05)$ weight loss in the HAEDC and MAEDC with 500, 1000 and $1500 \mathrm{mg} / \mathrm{kg}$ lost when compared with a control group and there was no significant difference $(p \geq 0.05)$ in the EAEDCtreated group (Table 1).

\section{Haematological parameters}

The effects of the daily oral administration of the HAEDC, EAEDC and MAEDC showed a statistically significant decrease $(p \leq 0.05)$ on the red RBC at different doses when compared with the control group. However, there was a significant $(p-0.05)$ increase in the MCV of HAEDC and EAEDC with doses of $1000 \mathrm{mg} / \mathrm{kg}$ and $1500 \mathrm{mg} / \mathrm{kg}$ when 


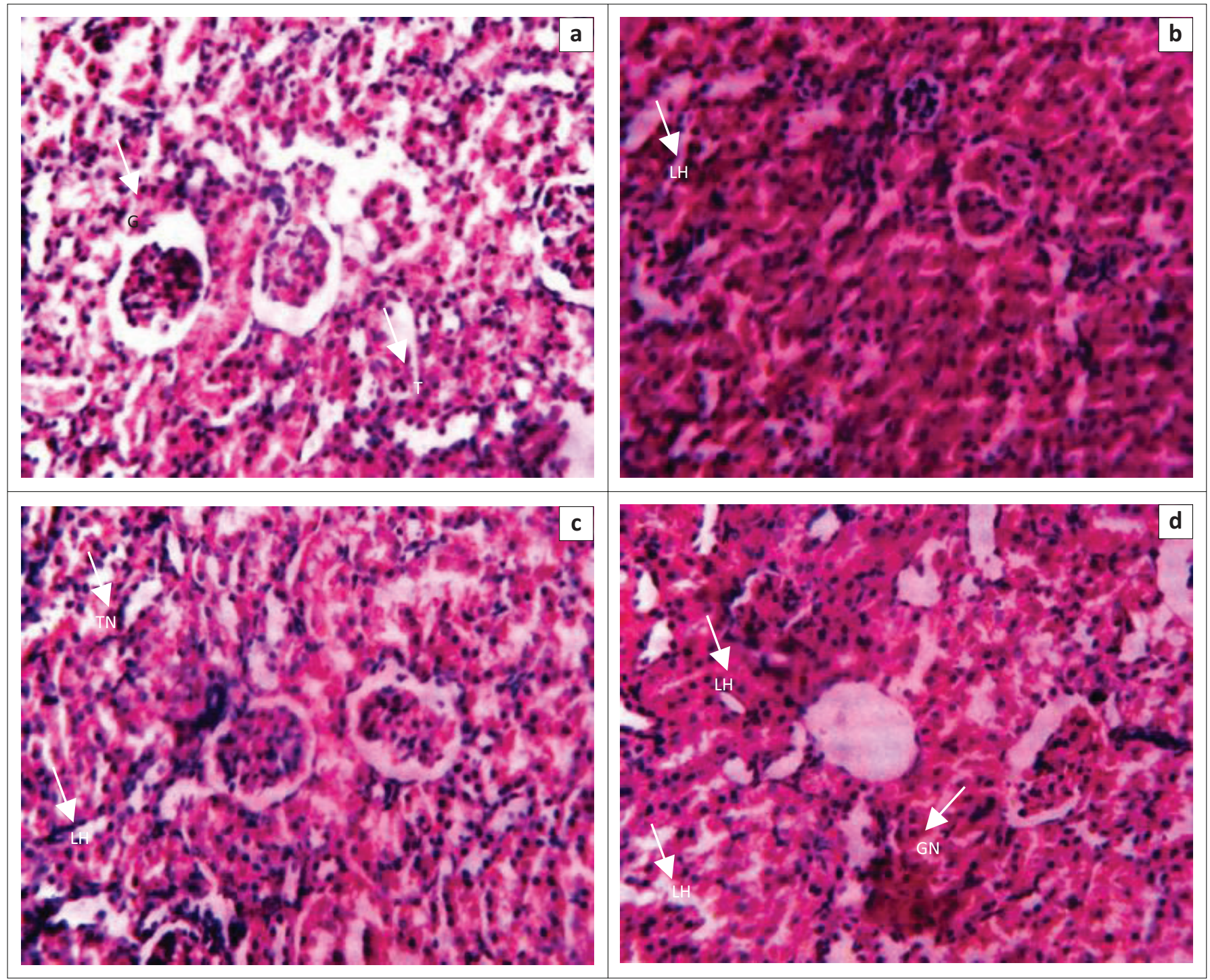

G, glomerular; T, normal tubules; LH, lymphocyte hyperplasia; TN, tubular necrosis; GN, glomerulus necrosis.

FIGURE 3: Photomicrograph showing the kidney section of (a) the control group ( $1 \mathrm{~mL} / \mathrm{kg}$ distilled water) shows normal architecture tubules ( $\mathrm{T}$ ) and glomerulus; (b) treated with $500 \mathrm{mg} / \mathrm{kg}$ of ethyl acetate extract shows moderate and slight lymphocyte hyperplasia; (c) treated with $1000 \mathrm{mg} / \mathrm{kg}$ of ethyl acetate extract shows slight lymphocyte hyperplasia; (d) treated with $1500 \mathrm{mg} / \mathrm{kg}$ of ethyl acetate extract shows slight tubular necrosis, slight glomerular necrosis with lymphocyte hyperplasia (haematoxylin and eosin stain; original magnification $\times 400$ ).

compared with the control group. Furthermore, EAEDC at a dose of $500 \mathrm{mg} / \mathrm{kg}$ showed a significant $(p-0.05)$ increase in the $\mathrm{MCH}$ when compared with the control group (Table 2).

\section{Biochemical parameters}

There was no significant difference between the serum liver biomarker, AST, alanine amino transferase (ALT), TP and ALB in the treated group and control group. However, there was a significant $(p-0.05)$ decrease in ALP of all the treated groups when compared with control group (Table 3 ).

There was no significant change in the serum kidney biomarkers (urea, sodium, potassium, creatinine and chloride) in the treated group when compared with the control group. However, there was a significant $(p-0.05)$ decrease in the serum bicarbonate level in HAEDC with $500 \mathrm{mg} / \mathrm{kg}, 1000 \mathrm{mg} / \mathrm{kg}$ and $1500 \mathrm{mg} / \mathrm{kg}$ and MAEDC with $1000 \mathrm{mg} / \mathrm{kg}$ and $1500 \mathrm{mg} / \mathrm{kg}$ body weight when compared with the control group (Table 4).

\section{Discussion}

The acute oral administration of up to $5000 \mathrm{mg} / \mathrm{kg} n$-hexane, ethyl acetate and methanol extracts neither showed mortality nor any toxic signs in the experimental rats. The extracts could be assumed as practically safe and non-toxic. This result is in agreement with Olorunnisola et al. (2012), Parasuraman et al. (2014), Ugbogu et al. (2016) and Adesegun et al. (2016) that reported that the acute toxicity of plants could be considered practically non-toxic and safe above the oral administration of $5000 \mathrm{mg} / \mathrm{kg}$.

Oral administration of the extracts ( $n$-hexane and methanol) led to a statistically significant decrease in body weight at $500 \mathrm{mg} / \mathrm{kg}, 1000 \mathrm{mg} / \mathrm{kg}$ and $1500 \mathrm{mg} / \mathrm{kg}$ at week 2 when compared with the initial body weight of Wistar rats at week 0 (Table 1), while the ethyl acetate extracts had no significant difference on the body weight. This reduction was a dose-dependent decrease in their body weight and was 


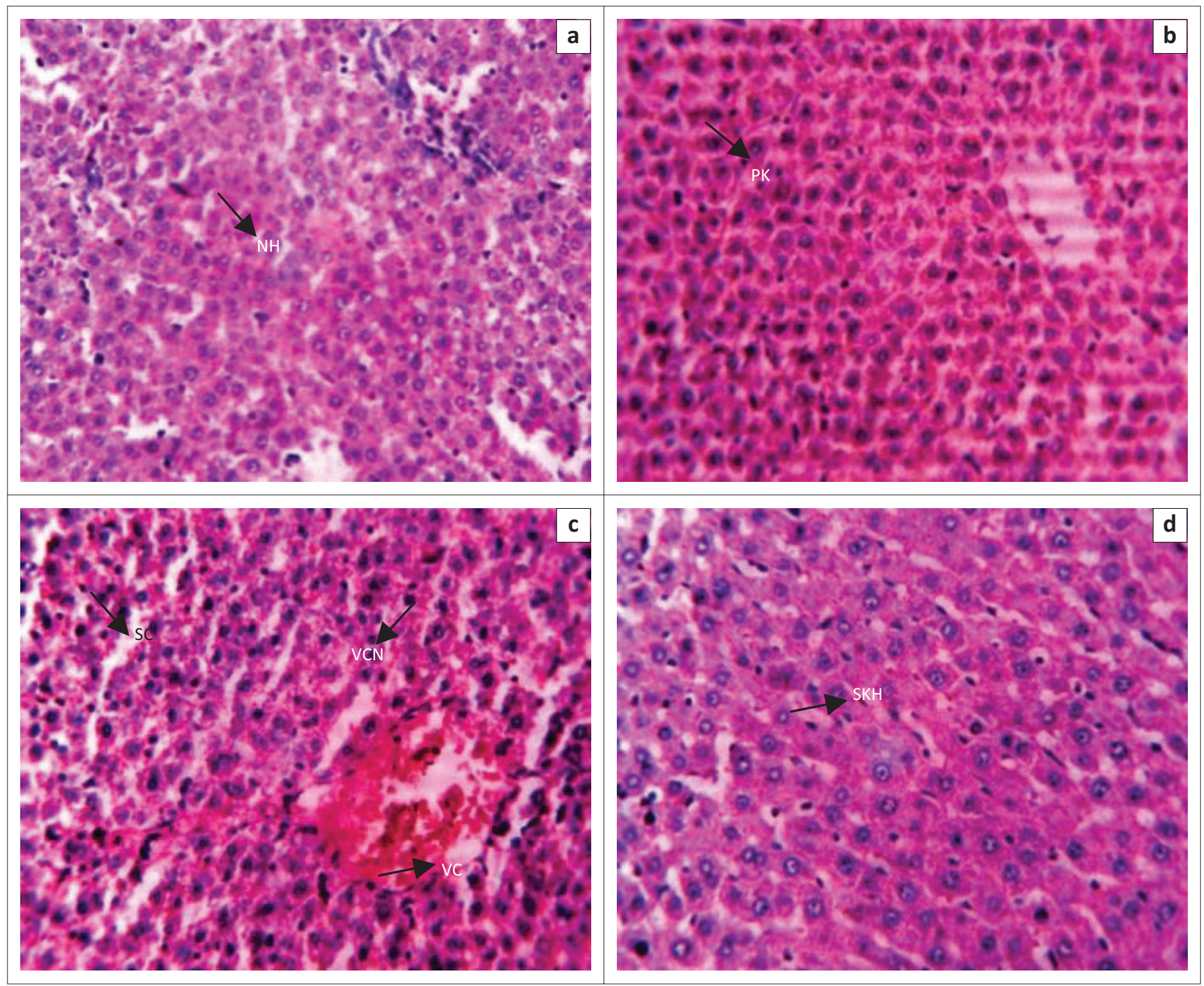

$\mathrm{NH}$, normal hepatocytes; VCN, vascular congestion necrosis; SC, sinusoidal congestion; PK, pyknosis of hyptocytes nucleus; SKH, Kupfer cell hyperplasia; VC, slight vacuolation necrosis.

FIGURE 4: Photomicrograph showing the liver section of (a) control group ( $1 \mathrm{~mL} / \mathrm{kg}$ distilled water) shows the normal hepatocytes; (b) treated with $500 \mathrm{mg} / \mathrm{kg}$ shows moderate pyknosis of hepatocytes nucleus; (c) treated with $1000 \mathrm{mg} / \mathrm{kg}$ shows vascular congestion sinusoidal congestion and slight vacuolation necrosis; (d) treated $1500 \mathrm{mg} / \mathrm{kg}$ shows slight Kupfer cell hyperplasia (haematoxylin and eosin stain; original magnification $\times 400$ ).

probably caused by the presence of some phytoconstituents in the extracts that may have interfered with the rat's appetite and food consumption. The body weight changes serve as a sensitive indication of the general health status of animals. Changes in body weight have been used as an indicator of adverse effects of drugs and chemicals (Grance et al. 2008; Nandy \& Datta 2012).

The haematopoietic system is one of the sensitive targets for toxic compounds and an important index of the physiological and pathological status in man and animals. The analysis of blood parameters is relevant to risk evaluation as the changes in haematological parameters have a high predictive value for human toxicity when the data are translated from animal studies (Olson et al. 2000). The haematological parameters of the extracts of $D$. carota aerial part showed a statistically significant difference $(p \leq 0.05)$ on the RBC at $500 \mathrm{mg} / \mathrm{kg}$, $1000 \mathrm{mg} / \mathrm{kg}$ and $1500 \mathrm{mg} / \mathrm{kg}$ when compared with the control group (Table 2). However, there was a mean decreased of the RBC on the extracts. This reduction of RBC could be the result of fatty acid or the invasion of foreign components like some classes of secondary metabolites present in the extracts that could interfere with the haematopoietic system, erythropoiesis, morphology, or osmotic fragility of the red blood cells because red blood cells are involved in the transportation of oxygen and carbon dioxide into the body (Guyton \& Hall 2000; Isaac et al. 2013). Thus, a reduced red blood cell count implies a reduction in the level of oxygen that would be carried to the tissues as well as the level of carbon dioxide returned to the lungs (Isaac et al. 2013; Soetan, Akinrinde \& Ajibade 2013). The extracts probably contained some classes of secondary metabolites that could interfere with the haematopoietic system. This result is comparable with the work of Guyton and Hall (2000) that reported a similar reduction in the red blood cells in some plant species. This probably showed that the extracts contained some haematopoietic-like principle that could reduce the red blood cell (Adeneye 2008; Palani et al. 2009; Wararut et al. 2012). 

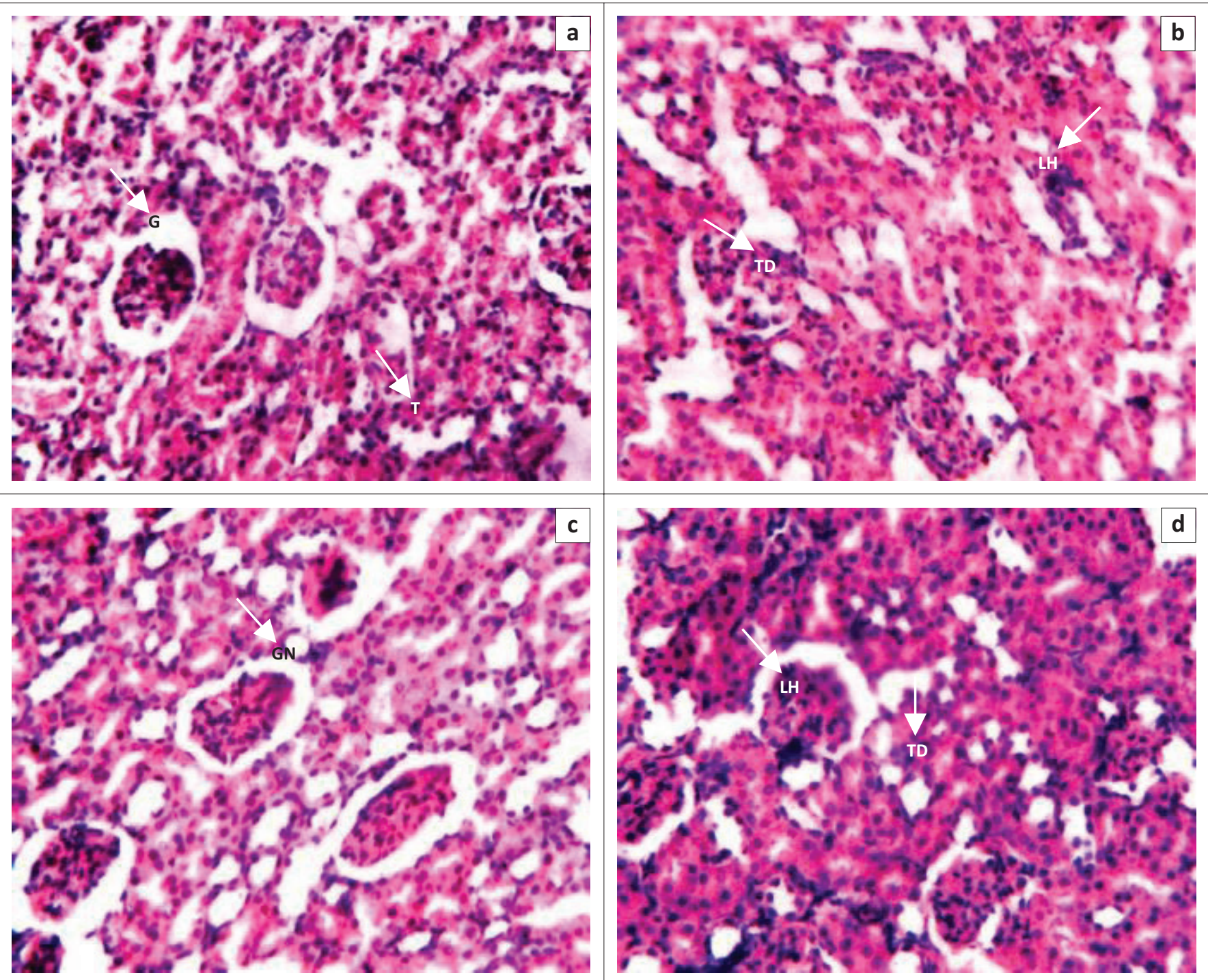

GN, glomerulus necrosis; T, normal tubules; TD, slight tubular distortion; NC, slight hepatic necrosis; LH, lymphocyte hyperplasia; HN, slight hepatocellular necrosis; G, glomerular.

FIGURE 5: Photomicrograph showing the kidney section of (a) control group ( $1 \mathrm{~mL} / \mathrm{kg}$ distilled water) shows the normal architecture tubules ( $\mathrm{T}$ ) and glomerulus; (b) treated with $500 \mathrm{mg} / \mathrm{kg}$ methanol extract slight tubular distortion and lymphocyte hyperplasia; (c) treated with $1000 \mathrm{mg} / \mathrm{kg}$ methanol extract shows slight glomerular necrosis; (d) treated with $1500 \mathrm{mg} / \mathrm{kg}$ methanol extract show slight tubular distortion and lymphocyte hyperplasia (haematoxylin and eosin stain; original magnification $\times 400$ ).

However, there was no statistically significant difference $(p \geq 0.05)$ in the WBC, Hgb and HCT in the extracts; this probably did not affect the immune systems but might be susceptible to infection. However, the results of the haematological parameter are within the internationally accepted reference range for each haematological parameter (Daramola et al. 2005; Kifayatullah et al. 2015; NseAbasi et al. 2014; Research Animal Resources 2009; Uboh et al. 2012). Liver function tests involve evaluating serum ALT, AST, ALP, bilirubin and ALB levels. The most commonly used indicators of liver damage are ALT and AST (Ramaiah 2011). These are enzymes normally found in liver cells that leak out of these cells into the bloodstream following an injury to the liver cells. These liver enzymes become elevated in liver cirrhosis, hepatitis, and hepatobiliary obstruction. ALT is localised primarily in the cytosol of hepatocytes and is considered to be a more sensitive marker of hepatocellular damage than AST (Saad et al. 2006). It can provide a quantitative assessment of the degree of damage sustained by the liver (Al-Mamary et al. 2002).
In this study, the liver function test (Table 3) showed a statistically significant decrease at $(p \leq 0.05)$ on the ALP of the extracts, but there was no statistically significant difference in the ALT, AST, TP and ALB. The significant decrease in the ALP may be indicative of liver injury in the animals.

Urea and creatinine are considered as good prognostic indicators of renal dysfunction and kidney failure for any toxic compound (Ashour, Yassin \& Abu 2006; Gnamani et al. 2008). As the kidneys become impaired, the creatinine level in the blood rises because of damage to the functional nephrons and consequently result in poor clearance by the kidneys (Aliyu et al. 2006). In the present study, the kidney function test (Table 4) of the extracts showed that there was no statistically significant difference at $p \leq 0.05$ when compared with the control group. Serum creatinine, urea and electrolytes such as sodium and calcium were not affected by the treatment of the extract. However, there was a statistically significant increase of bicarbonate $(\mathrm{mmol} / \mathrm{L})$, which was dose-dependent 

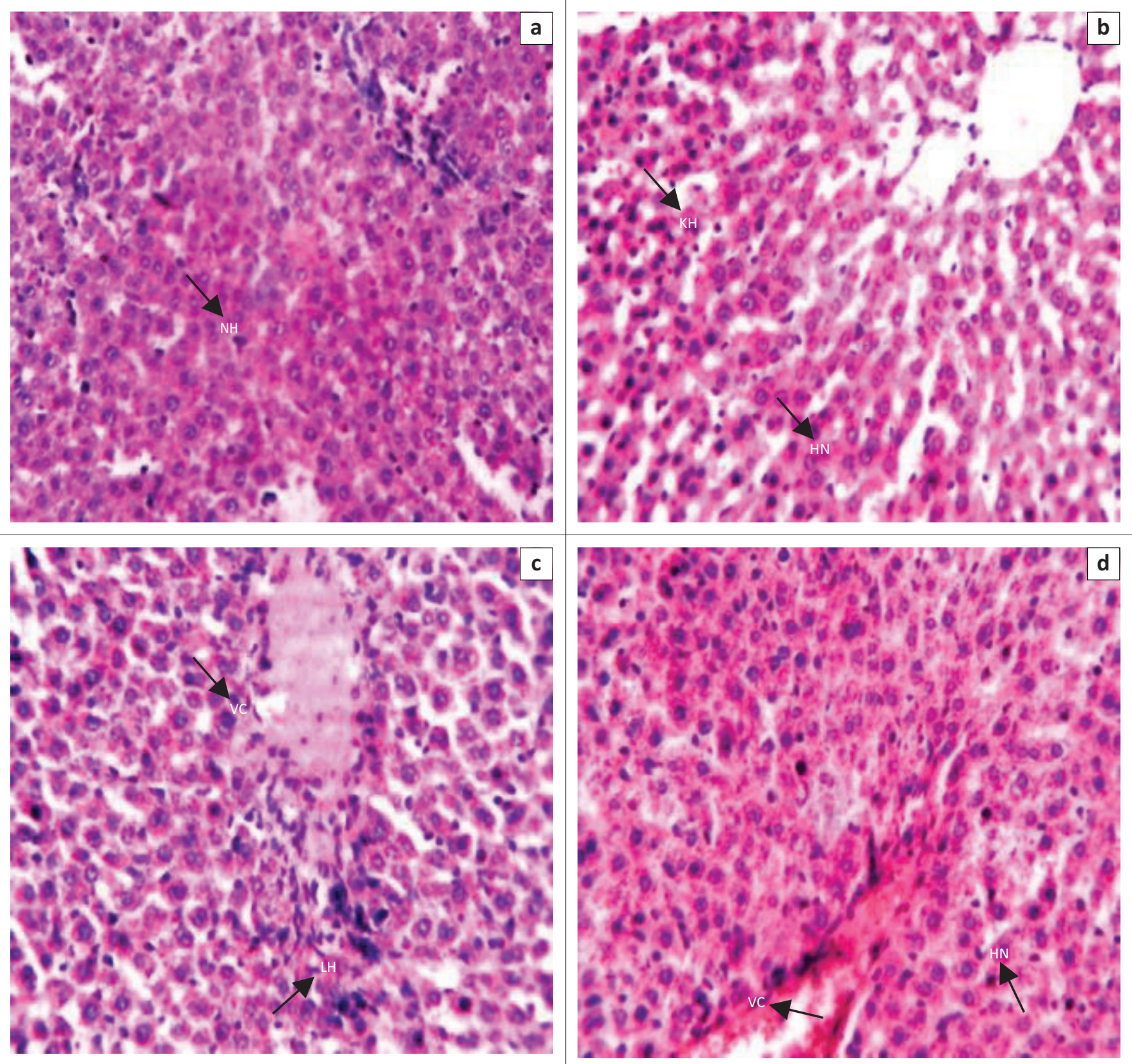

G, glomerulus; T, normal tubules; HN, slight hepatocellular necrosis; VC, vascular congestion; LH, lymphocyte hyperplasia; $\mathrm{NH}$, normal hepatocytes.

FIGURE 6: Photomicrograph from the liver section of (a) control group (1 mL/kg distilled water) shows the normal hepatocytes; (b) treated with $500 \mathrm{mg} / \mathrm{kg}$ methanol extract shows slight hepatocellular hyperplasia; (c) rat treated with $1000 \mathrm{mg} / \mathrm{kg}$ methanol extract shows vascular congestion with lymphocyte hyperplasia; (d) treated with $1500 \mathrm{mg} / \mathrm{kg}$ methanol extract shows vascular congestion with lymphocyte hyperplasia and slight hepatocellular necrosis (haematoxylin and eosin stain; original magnification $\times 400$ ).

in the extracts when compared with the control group. This increase may have influenced the regulation in the levels of other kidney parameters (urea, potassium, creatinine and chloride). This is an indication that the D. carota aerial part may not be relatively safe for consumption. Histopathological examination is the gold standard for evaluating treatmentrelated pathological changes in tissues and organs (OECD 2008). The histopathological effects (Figures 1-6) of the extracts at $500 \mathrm{mg} / \mathrm{kg}$ showed moderate and slight tubular necrosis in the kidney, while the liver had slight hepatic necrosis with moderate lymphocyte hyperplasia in all of the extracts. Also, $1000 \mathrm{mg} / \mathrm{kg}$ and $1500 \mathrm{mg} / \mathrm{kg}$ of the extracts showed moderate lymphocyte hyperplasia in the kidney, while vascular congestion with Kupfer cell hyperplasia was observed in the liver. The $500 \mathrm{mg} / \mathrm{kg}$ dose of the extracts showed that the lowest dose produces a slightly detectable toxic reaction which was also reported by Leclair and Willard (1970). Because the toxicity target organs are mainly the liver and kidney, the alteration may cause liver and kidney diseases when consumed even at low doses (Okunlola et al. 2012; Soetan et al. 2013).

\section{Conclusion}

The sub-acute toxicity study showed that the aerial parts of the D. carota are not safe for consumption when consumed as a 
livestock feed for animals or vegetables for man. The doses are capable of causing significant liver and kidney injury and may also have an adverse effect on the haematopoietic system. The study suggested further investigation on the chronic toxicity and isolation of the toxic components in the aerial part.

\section{Acknowledgements Competing interests}

The authors declare that they have no financial or personal relationships that may have inappropriately influenced them in presenting this article.

\section{Authors' contributions}

A.E.A., A.A. and I.G. designed the study and gave directions, gathered information and wrote the first draft of the article. N.A. and L.O.U. edited, proofread and participated in the data analysis of the article and put it into the journal format.

\section{Funding information}

This research received no specific grant from any funding agency in the public, commercial or not-for-profit sectors.

\section{Data availability statement}

Data sharing is not applicable to this article as no new data were created or analysed in this study.

\section{Disclaimer}

The views and opinions expressed in this article are those of the authors and do not necessarily reflect the official policy or position of any affiliated agency of the authors.

\section{References}

Adeneye, A.A., 2008, 'Haematopoetic effect of methanol seed extract of Citrus paradise Macfad (grape fruit) in Wistar rats', Biomedical Research 19(1), 23-26.

Adesegun, S.A., Celestina, I.O. \& Coker, H.A., 2016, 'Analgesic and antioxidant activities of Stem Bark extract and fractions of Petersianthus macrocarpus', Pharmacognosy Research 8(3), 181-185. https://doi.org/10.4103/0974-8490.182912

Ali-Abdel-Rahman, A., Njwen, A., Louis, C., Steve, C., Rebecca, P.D., Evaristus, E. et al. 2011, 'The safety and regulation of natural products used as foods and food ingredients', Toxicological Sciences 123(2), 333-348. https://doi.org/10.1093/ toxsci/kfr198

Aliyu, R., Adebayo, A.H., Gatsing, D. \& Garba, I.H., 2006, 'The effects of ethanolic leaf extract of Commiphora africana (Burseraceae) on rat liver and kidney function', Journal of Pharmacology and Toxicology 2(4), 373-379. https://doi.org/10.3923/ jpt.2007.373.379

Al-Mamary, M., Al-Habori, M., Al-Aghbari, A.M. \& Baker, M.M., 2002, 'The investigation into the toxicological effects of Catha edulis leaves; a short-term study in animals', Phytotherapy Research 16(2), 127-132. https://doi.org/10.1002/ptr.835

Ashour, A., Yassin, M. \& Abu, A.M., 2006, 'Blood, serum glucose and renal parameters in lead-loaded albino rats and treatment with some chelating and natural oils', Turkish Journal of Biology 31, 25-34.

Ayeni, E.A., Ahmed, A., Ibrahim, G., Vallada, A. \& Muhammad, Z.H., 2018 'Phytochemical, nutraceutical and antioxidant studies of the aerial parts of Daucus carota L. (Apiaceae)', Journal of Herbmed Pharmacology 7(2), 68-73. https://doi.org/10.15171/jhp.2018.12

Baghiani, A., Boussoualim, N., Trabsa, H., Aouachria, S. \& Arrar, L., 2013, 'In vivo free radical scavenging, antihemolytic activity and antibacterial effects of Anchusa Azurea extracts', International Journal Medicine and Medical Science 46, 1113-1118.

Bello, O.M., Jagaba, S.M., Bello, O.E., Ogbesejana, A.B., Dada, O.A., Adetunji, C.A. \& Abukakar, S.M., 2019, 'Phytochemistry, pharmacology and perceived health uses of non-cultivated vegetable Cyphostemma adenocaule (Steud. Ex A. Rich.) Desc. ex Wild and R.B. Drumm: A review', Scientific African 2(1), 1-10. https://doi.org/ 10.1016/j.sciaf.2019.e00053
Brain, D.R. \& Tuner, T.D., 1975, Extraction procedures. The practical evaluation of phytopharmaceuticals, Wright Scentechnical, Bristol, UK, pp. 45, 75-85, 98-107.

Dalvir, K., Khushminder, K.C., Pavneet, K. \& Ramandeer, K., 2016, 'Carrot plant-a potential source of high-value compounds and biological activities: A review', Proceedings of Indian National Science Academy 82(4), 1237-1248. https://doi. org/10.16943/ptinsa/2016/48573

Daramola, J.O., Adeloye, A.A., Fatoba, T.A. \& Soladoye, A.O., 2005, 'Haematological and biochemical parameters of West African Dwarf goats', Livestock Research for Rural Development 17(8), 95.

FAO/WHO, 2002, Joint FAO/WHO Working Group Report on drafting guidelines for the evaluation of probiotics in food, World Health Organization, London, Ontario, Canada.

Fasuyi, A.O., 2006, 'Nutritional potentials of some tropical vegetable meals, chemical characterization and functional properties', Africa Journal of Biotechnology 5(1) 49-53.

Gandhare, B., Kavimani, S. \& Rajkapoor, B., 2013, 'Acute and subacute toxicity study of methanolic extract of Ceiba pentandra (L.) Gaertn. on rats', Journal of Scientific Research 5(2), 315-324. https://doi.org/10.3329/jsr.v5i2.11800

Gnamani, A., Sudha, M., Deepa, G. \& Sadulla, S., 2008, 'Hematological and biochemical effects of polyphenolics in animal models', Chemosphere 72(9), 1321-1326. https://doi.org/10.1016/j.chemosphere.2008.04.028

Grance, S.R.M., Teixeira, M.A., Leite, R.S. \& Veira, M.C., 2008, 'Baccharis trimera: Effect on hematological and biochemical parameters and hepatorenal evaluation in pregnant rats', Journal of Ethnopharmacology 117(1), 28-33. https://doi. org/10.1016/j.jep.2007.12.020

Guyton, A.C. \& Hall, J.E., 2000, Textbook of medical physiology, 10th edn., Harcourt International Edition, W.B Saunder Company, Philadelphia, PA, pp. 279-281.

Heywood, V.H., Brummitt, R.K., Culham, A. \& Seberg, O., 2008, Apiaceae. In: Flowering plant families of the world, Firefly Books, New York, pp. 35-38.

Isaac, L.J., Abah, G., Akpan, B. \& Ekaette, I.U., 2013, 'Haematological properties of different breeds and sexes of rabbits', in Proceedings of the 18th annual conference of Animal Science Association of Nigeria, Abuja, September 08-12, 2013, pp. 24-27.

Jaijoy, K., Soonthornchareonnon, N., Lertprasertsuke, N., Panthong, A. \& Sireeratawong, S., 2011, 'Acute and chronic oral toxicity of standardized water extract from the fruit of Phyllanthus emblica Linn', International Journal Applied Research in Natural Products 3(1), 48-58. https://doi.org/10.1055/s-0031-1282780

Kifayatullah, M., Mustafa, M.S., Sengupta, P., Moklesur, R.S., Arindam, D. \& Sreemoy, K.D., 2015, 'Evaluation of the acute and sub-acute toxicity of the ethanolic extract of Pericampylus glaucus (Lam.) Merr. in BALB/c mice', Journal of Acute Disease 4(4), 309-315. https://doi.org/10.1016/j.joad.2015.06.010

Latifou, L., Abdou Madjid, O.A., Rafatou, A.A.A., Anatole, L. \& Ambaliou, S., 2016, 'Antimicrobial, antioxidant, toxicity and phytochemical assessment of extracts from Acmella uliginosa, a leafy-vegetable consumed in Bénin, West Africa', BMC Complementary and Alternative Medicine 16, 1-11. https://doi.org/10.1186/ s12906-016-1014-3

Leclair, J.M. \& Willard, J.W., 1970, Guide for the preparation of submissions on tolerances for incidental contaminants and agricultural chemicals in food, Food and Drug Directorate, Department of National Health and Welfare, Ottawa, Canada.

Nandy, S. \& Datta, R., 2012, 'Acute and sub-acute toxicity studies of methanol leaves of Pterospermium acerifolium L. Wild in rodents', International Journal of Pharmaceutical Life Science 3, 1519-1529.

NseAbasi, N.E., Mary, E.W., Uduak, A. \& Edem, E.A.O., 2014, 'Haematological parameters and factors affecting their values', Agricultural Science 2(1), 37-47. https://doi.org/10.12735/as.v2i1p37

Obidike, I. \& Salawu, O., 2013, Screening of herbal medicines for potential toxicities, Pharmacology, toxicology and pharmaceutical science. New insight in toxicity and drug testing, pp. 63-67, Pub. Intech, London.

Okunlola, D.O., Olorunisomo, A.O., Aderinola, A.O., Agboola, A.S. \& Omole, O.G., 2012, 'Hematology and serum quality of red Sokoto goats fed Baobab (Adansonia digitata) fruit meal as a supplement to guinea grass (Panicum maximum)', in Proceedings of the 17th annual conference of Animal Science Association of Nigeria, Abuja, September 09-13, 2012, pp. 427-433.

Olorunnisola, O.S., Bradley, G. \& Afolayan, A.J., 2012, 'Acute and sub-chronic toxicity studies of methanolic extract of Tulbaghia violacea rhizomes in Wistar rats', African Journal of Biotechnology 11(83), 14934-14940.

Olson, H., Bretton, G., Robinson, B., Thomas, K., Monro, A., Kolaja, G. et al., 2000 'Concordance of the toxicity of pharmaceuticals in human and animals', Regulatory Toxicology and Pharmacology 32(1), 56-67. https://doi.org/10.1006/ rtph.2000.1399

Orech, F.O., Akenga, T., Ochora, J., Friis, H. \& Aagaard-Hansen, J., 2005, 'Potential toxicity of some traditional leafy vegetables consumed in Nyang'oma Division, Western Kenya', African Journal of Food and Nutritional Sciences 5(1), 1-13.

Organization for Economic Cooperation Development (OECD), 2008, 'Repeated dose 28-day oral toxicity study in rodents', in OECD guideline for testing chemicals, vol. 407, pp. 1-8, OECD, Paris.

Organizati on for Economic Cooperation Development (OECD), 2011, Guidance document on the recognition, assessment, and use of clinical signs as humane endpoints for experimental animals used in safety evaluation, Environmental Health and Safety Monograph Series on Testing and Assessment No. 19, OECD, Paris.

Palani, S., Senthilkumar, B., Praveen, R., Kumar, P., Devi, K., Venkatesan, D. et al., 2009, 'Effect of the ethanolic extract of Indigofera barberi (L.) in acute acetaminopheninduced nephrotoxic rats', Advanced Biotechnology 25(Supplement), 28-31. https://doi.org/10.1016/j.nbt.2009.06.989

Parasuraman, S., 2011, 'Toxicological screening', Journal of Pharmacology and Pharmacotherapy 2(2), 74-95. https://doi.org/10.4103/0976-500X.81895 
Parasuraman, S., Raveendran, R., Rajesh, N.G. \& Nandhakumar, S., 2014, 'Sub-chronic toxicological evaluation of cleistanthin A and cleistanthin B from the leaves of toxicological evaluation of cleistanthin A and cleistanthin B from the leaves of
Cleistanthus collinus (Roxb.)', Toxicology Report 1, 596-611. https://doi. Cleistanthus collinus (Roxb.)',
org/10.1016/j.toxrep.2014.08.006

Park, J.H., Choi, K.H. \& Kwak, H.S., 2011, 'Single and 14-day repeat-dose toxicity of crosslinked B-cyclodextrin in rats', International Journal of Toxicology 30(6), 700-706. https://doi.org/10.1177/1091581811419678

Pimenov, M.G. \& Leonov, M.V., 2004, 'The Asian Umbelliferae biodiversity database (ASIUM) with particular reference to south-west Asian taxa', Turkish Journal of Botany 28, 139-145.

Ramaiah, S.K., 2011, 'Preclinical safety assessment: Current gaps, challenges, and approaches to identifying translatable biomarkers of the drug-induced liver' Clinical Laboratory Medicine 31(1), 161-172. https://doi.org/10.1016/j. cll.2010.10.004

Research Animal Resource, 2009, Reference values for laboratory animals: Norma haematological values, RAR Websites, RAR, University of Minnesota, viewed from 13 June 2018, http://www.ahc.umn.edu/rar/refvalues.html.

Saad, B., Azaizeh, H., Abu-Hijleh, G. \& Said, O., 2006, 'Safety of traditional Arab Herbs', Evidence-Based Complementary and Alternative Medicine 3(4), 433-439. https:// doi.org/10.1093/ecam/nel058

Sanders, M.E., Akkermans, M.A., Haller, D.C., Hammerman, C., Heimbach, J., Hörmannsperger, G. et al., 2010, 'Safety assessment of probiotics for human use', Gut Microbes 1(3), 1-22. https://doi.org/10.4161/gmic.1.3.12127
Sharma, H.P. \& Kumar, R.A., 2013, 'Health security in ethnic communities through nutraceutical leafy vegetables', Journal of Environmental Research and Development 7(4), 1423-1429.

Shelly, L., 2012, The benefits of the use of Daucus carota; in the herbal preparations, Cain Page 1, Aurora, CO.

Soetan, K.O., Akinrinde, A.S. \& Ajibade, T.O., 2013, 'Preliminary studies on the hematological parameters of cockerels fed raw and processed guinea corn (Sorghum bicolor)', in Proceedings of 38th annual conference of Nigerian Society for Animal Production, Port Harcourt, March 17-20, 2013, pp. 49-52.

Uboh, F.E., Usoh, I.F., Nwankpa, P. \& Obochi, G.O., 2012, 'Effect of oral exposure to nitrocellulose thinner on haematological profiles of Male Albino Wistar rats',
American Journal of Biochemistry and Molecular Biology 2(4), 227-234. https:// American Journal of Biochemistry and
doi.org/10.3923/ajbmb.2012.227.234

Ugbogu, E.A., Emmanuel, O., Iheanyichukwu, E., Friday, U., Emmanuel, A. \& Chinyere, G.C., 2016, 'Toxicological assessment of the aqueous dried leaf extracts of Senna alata L. in Wistar rats', African Journal of Pharmacy and Pharmacology 10(34), 709-717. https://doi.org/10.5897/AJPP2016.4609

Wararut, B., Supap, S., Siriwadee, C. \& Kanokporn, S., 2012, 'Evaluation of biochemical, hematological and histopathological parameters of albino rats treated with Stemona aphylla Craib. Extract', Journal of Medicinal Plants Research 6(27), 4429-4435. https://doi.org/10.5897/JMPR12.595

Yadav, R.K., Kalia, P., Kumar, R. \& Jain, V., 2013, 'Antioxidant and nutritional activity studies of green leafy vegetables', International Journal of Agriculture Food studies of green leafy vegetables', Inter
Science and Technology 4(7), 707-112. 